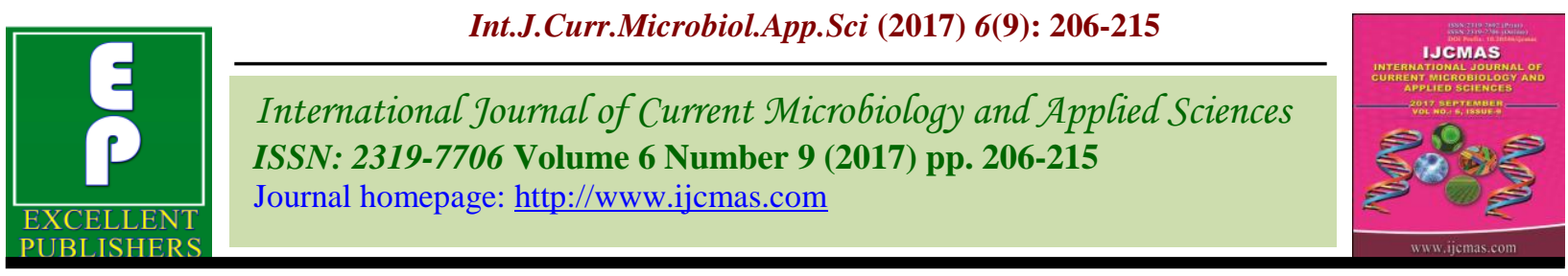

Original Research Article

https://doi.org/10.20546/ijcmas.2017.609.028

\title{
Varietal Response on Plantlet Regeneration through Macro-Propagation in Banana (Musa spp. L.)
}

\author{
D.U. Pujar*, A.M.Shirol, U.U. Pujar, S.S. Hiremath and P.R. Choudhury \\ University of Horticultural Sciences, Bagalkot, Udyanagiri, \\ Bagalkot-587102, Karnataka \\ *Corresponding author
}

A B S T R A C T

\begin{tabular}{|l|}
\hline Key w o r d s \\
Banana, Macro- \\
propagation, \\
Varieties, Ney \\
Poovan, Grand \\
Naine, Rajapuri, \\
Regeneration.
\end{tabular}

Studies were conducted to know varietal response on plantlet regeneration through macropropagation in banana. Many varieties and cultivars were grown in different regions of country and there is a need to know which variety will respond well to macro-propagation. Three commercially cultivated varieties were taken for experiment viz., Ney Poovan, Rajapuri and Grand Naine. Major problem in cultivation of banana is supply of quality planting material. In-vitro propagation is tried, but is not easily affordable by normal farmer/ gardener and the same time traditional production (in field) of planting material will not be sufficient. Hence, macro-propagation was tried to see the practicability in using it for large scale multiplication which falls in between traditional and tissue culture method of propagation. Banana has strong apical dominance, which when suppressed will give rise to many side suckers. This principle was used in macro-propagation. Different varieties/cultivars were used to know the regeneration capacity of corm through macropropagation. Among different varieties/cultivars used Grand Naine has produced significantly higher number of primary buds per corm, number of plantlets after secondary decapitation, total number of plantlets per corm and days taken for first bud emergence.

\section{Introduction}

Banana is an antique fruit crop of world, which is also known as apple of paradise (Musa spp.) It is the most important world traded tropical fruit. India is the largest producer of banana and plantain in the world. But one of the common limiting factors for the extensionof plantation of banana is difficulty in obtaining planting material, its limited sucker production and slow development (Tezenas du moncel, 1985). In India, banana is largely grown by small and marginal farmers and they contribute to more than 90 per cent of the holdings. Farmers usually depend on natural regeneration of plants for the supply of such materials (Swennen, 1990 and Faturoti et al., 2002).
Natural regeneration is very slow in banana due to hormone mediated apical dominance. Rapid production of planting materials can be achieved through in-vitro propagation but require more sophisticated technique, skill, care to handle and also not easily affordable by small farmers. Therefore, user friendly technique that requires little technical skills or equipment would prove more attractive to adoption by small scale farmers. Recently the plantain and banana improvement programme of the International Institute of Tropical Agriculture (IITA), Nigeria, advance the use of a macro-propagation method for increasing sucker multiplication at farm level. It can be achieved by mechanical means through 
complete or partial decapitation or by detached corm techniques.

\section{Materials and Methods}

The experimental material comprised of different varieties/cultivar viz., Ney Poovan $\left(\mathrm{T}_{1}\right)$, Rajapuri $\left(\mathrm{T}_{2}\right)$ and Grand Naine $\left(\mathrm{T}_{3}\right)$ as a plant material which was collected from germplasm collections of AICRP on fruits (Banana and Sapota) at Kittur Rani Channamma College of Horticulture, Arabhavi, Karnataka, India. Healthy disease free sword suckers were selected; those rhizomes were pared to remove all old roots including the superficial layers, then apical meristem was removed to a depth of 2-3 cm and corm was given a criss cross incisions to a depth of 1-1.5 $\mathrm{cm}$ ending down to a rhizome collar. Later these corms were dipped in 1 per cent Bavistin solution for 5 minutes to eradicate surface pathogens and shade dried for 20 minutes. Such prepared corms were taken for planting and regular watering was done. Standardized growing media (from earlier studies) was used i.e., combination of Sawdust and FYM (1:1) and chemical treatment (from earlier studies) BAP $40 \mathrm{ppm}$. Sawdust was collected from the nearby sawmill and FYM from field. Media combination was prepared at equal ratio (1:1) and filled in black polybag of $42 \times 40 \mathrm{~cm}$ size.As all the studies were done in the nursery under moderate temperature and light conditions, Completely Randomised Design (CRD) was employed for the experiments. The data were subjected to analysis of variance (ANOVA) as suggested by Panse and Sukhatme (1967). Critical difference values were calculated at five per cent probability where ' $F$ ' test was significant.

\section{Results and Discussion}

Macro-propagation is a technique in which apical dominance is suppressed to stimulate lateral bud development and increased suckering rate can be achieved through decapitation of a sucker.

\section{Number of days taken for first bud emergence}

Ney Poovan recorded significantly the lowest number of days for first bud emergence (30.80 days), which is on par with Grand Naine (34.71 days).

However, another genotype Rajapuri recorded the more number of days for first bud emergence with non-significant results (43.71 days) (Table 1).

Varieties Ney Poovan and Grand Naine (Anonymous, 2012) produced early bud emergence which are on par with each other but differed significantly from other variety Rajapuri. This suggested that to get early bud emergence either Ney Poovan or Grand Naine were more suitable among the three varieties tested. This can be due to genomic differences among the three varieties. These results are supported by Adane, (2015) in tissue culture for faster multiplication rate.

\section{Number of days taken for second decapitation}

Cv. Ney Poovan recorded significantly the minimum number of days taken for second decapitation (61.42 days).However other genotypes like Rajapuri and Grand Naine recorded the more number of days for second decapitation with non-significant result (70.20 days and 72.25 days) (Table 1).

Number of days taken for second decapitation showed significant difference between Ney Poovan from Grand Naine, however Rajapuri is on par with Ney Poovan. These results are contradicting earlier reports (Anonymous, 2012). This indicates that for getting early plantlets, preference will be towards Ney Poovan compared to other two varieties. 


\section{Number of primary buds per corm}

Cv. Grand Naine recorded significantly the highest number of primary buds per corm (3.74), which is on par with Rajapuri (3.68). However, another genotype Ney Poovan recorded the less number of buds per corm with non-significant (2.74) (Table 2, Figure 1 and Plate 2).

Cultivars Grand Naine and Rajapuri produced more number of buds which are on par with each other but differed significantly from other variety Ney Poovan. This indicates that both varieties Grand Naine and Rajapuri produces more number of buds compared to Ney Poovan. Since Grand Naine variety respond well to tissue culture, (Adane, 2015) same result was noticed in this experiment.

\section{Number of plantlets produced after secondary decapitation}

Number of plantlets produced after second decapitation showed non-significant results for all three varieties (Table 2). However maximum number of plantlets after second decapitation (15.02 and 14.25) is noticed in Grand Naine and Rajapuri respectively and less number of plantlets (13.54) produced in $\mathrm{Cv}$. Ney Poovan (Figure 2 and Plate 2).

Number of plantlets after secondary decapitation did not show significant result among any of the treatments, however $\mathrm{T}_{3^{-}}$ Grand Naine produced maximum number of plantlets after second decapitation compared to other two varieties (Anonymous, 2012). All three varieties were on par with each other.

\section{Total number of plantlets produced per corm}

Number of plantlets produced per corm showed non-significant results (Table 2 and Figure 3). However maximum number of plantlets produced per corm is noticed in
Grand Naine (18.71) and Rajapuri (18.00) and the least (16.40) in Ney Poovan.

Totalnumber of plantlets did not show significant result among any of the treatments, however, Grand Naine produced maximum number of plantlets compared to other two varieties (Anonymous, 2012). All three varieties were on par with each other. These results indicated that Grand Naine recorded more number of plantlet regeneration rate followed by Rajapuri and Grand Naine because of varietal difference. Similar results were found with tissue cultured plantlets (Adane, 2015). Genome 'AAA' showed good response towards tissue culture, reason might be due to genome composition 'AAA'. As 'B genome' in genome constitution, rate of plantlet regeneration will be at lower rate. This was also reported in many tissue culture studies by (Adane, 2015). Since Grand Naine has genome AAA, it showed better results in terms of plantlet regeneration.

\section{Number of primary roots}

Cultivar Ney Poovan recorded significantly the highest number of primary roots (17.31) where as other two genotypes (Rajapuri- 7.80 and Grand Naine-6.48) recorded nonsignificant results for number of primary roots (Table 3 and Plate 2). Variety Ney Poovan showed significant difference compared to other varieties in case of number of primary roots. Whereas other two varieties such as Grand Naine and Rajapuri were on par with each other.

Ney Poovan produced more number of primary roots followed by Rajapuri and Grand Naine, these results are in contradicting the earlier reports with (Anonymous, 2012). These results indicate that Ney Poovan produces healthy plantlet with more number of primary roots that will be helpful in better establishment of plant. 


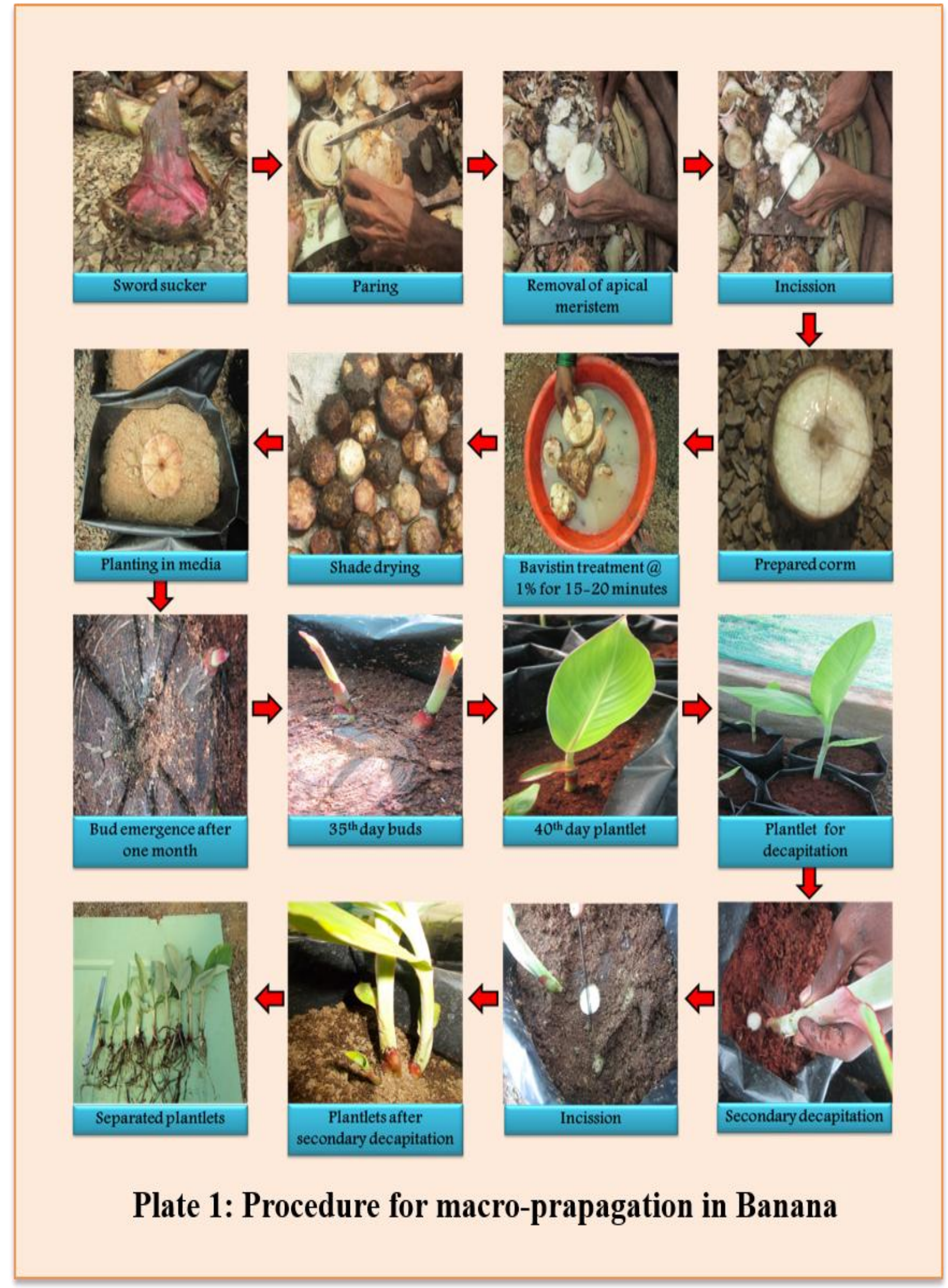



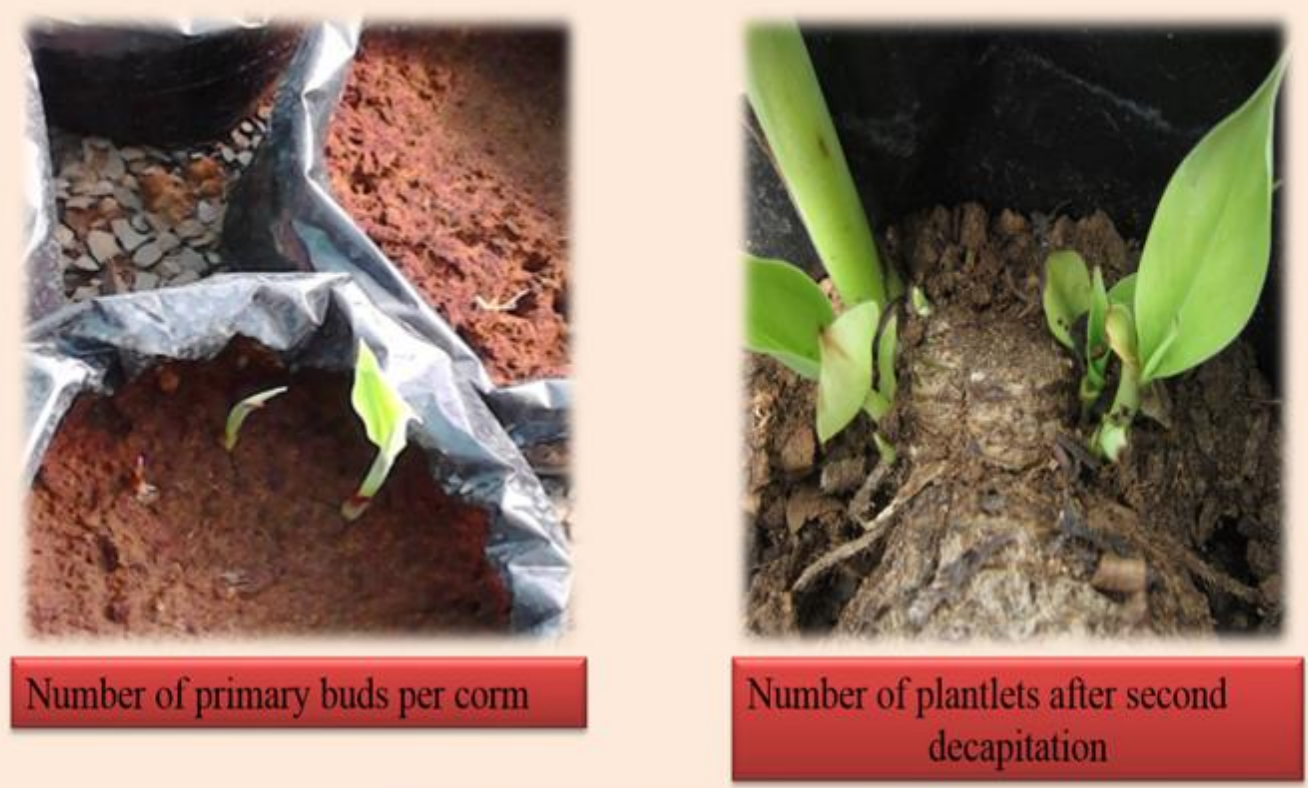

T3: Grand Naine (Musa AAA)

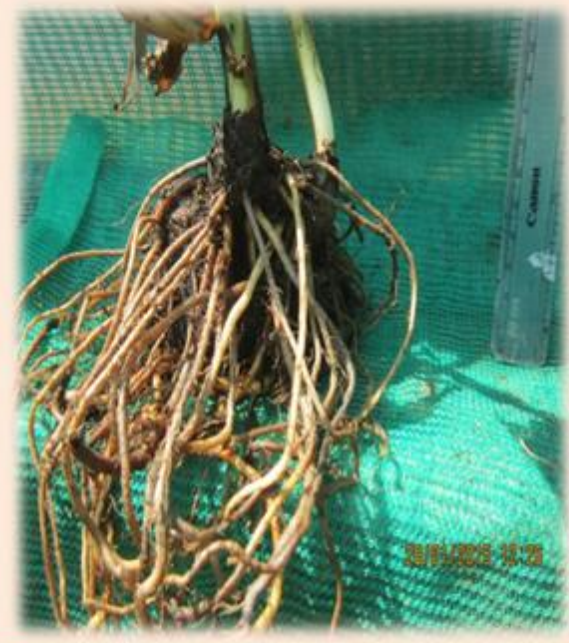

Number of primary roots per plantlet

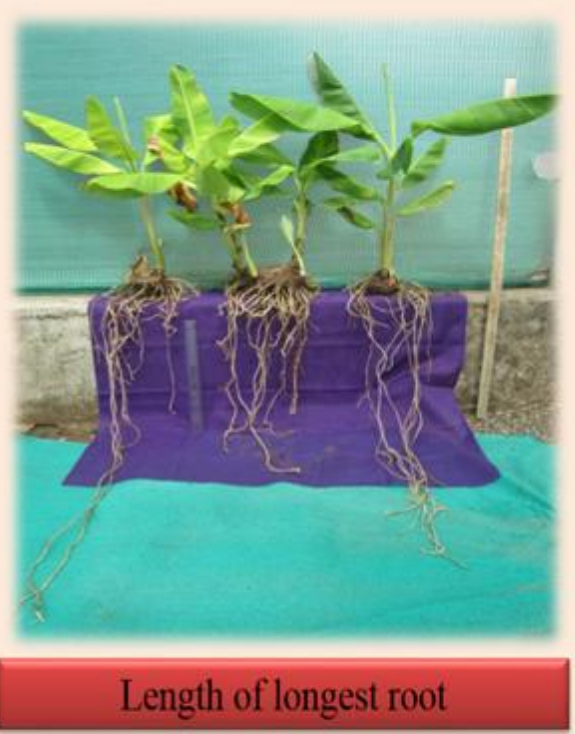

T1: Ney Poovan (Musa AB)

Plate 2: Varietal response to plantlet regeneration and root characters in macropropagation 
Fig.1 Varietal response to macro propagation on number of primary buds per corm

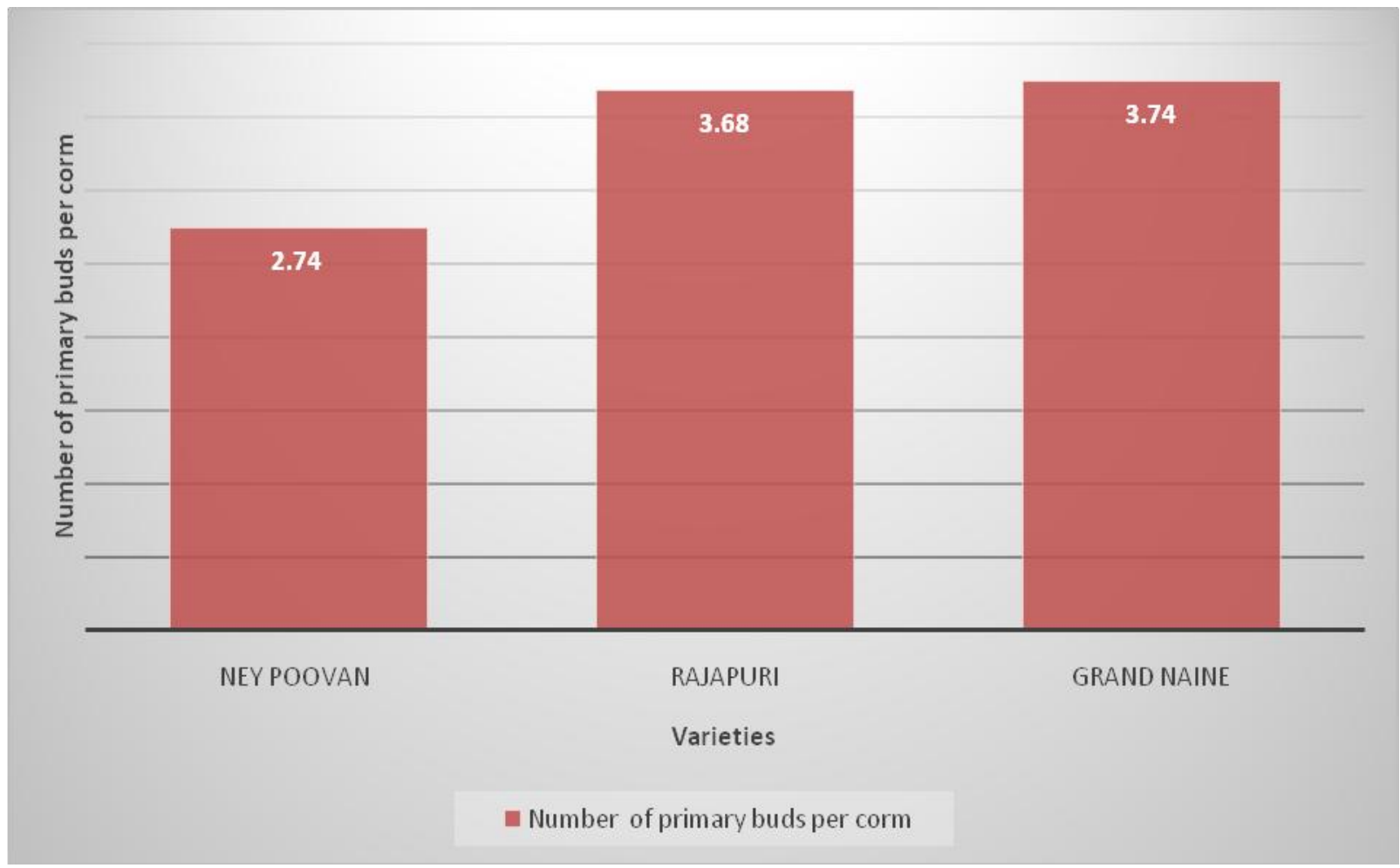

Fig.2 Varietal response to macro-propagation on number of plantlets produced after second decapitation

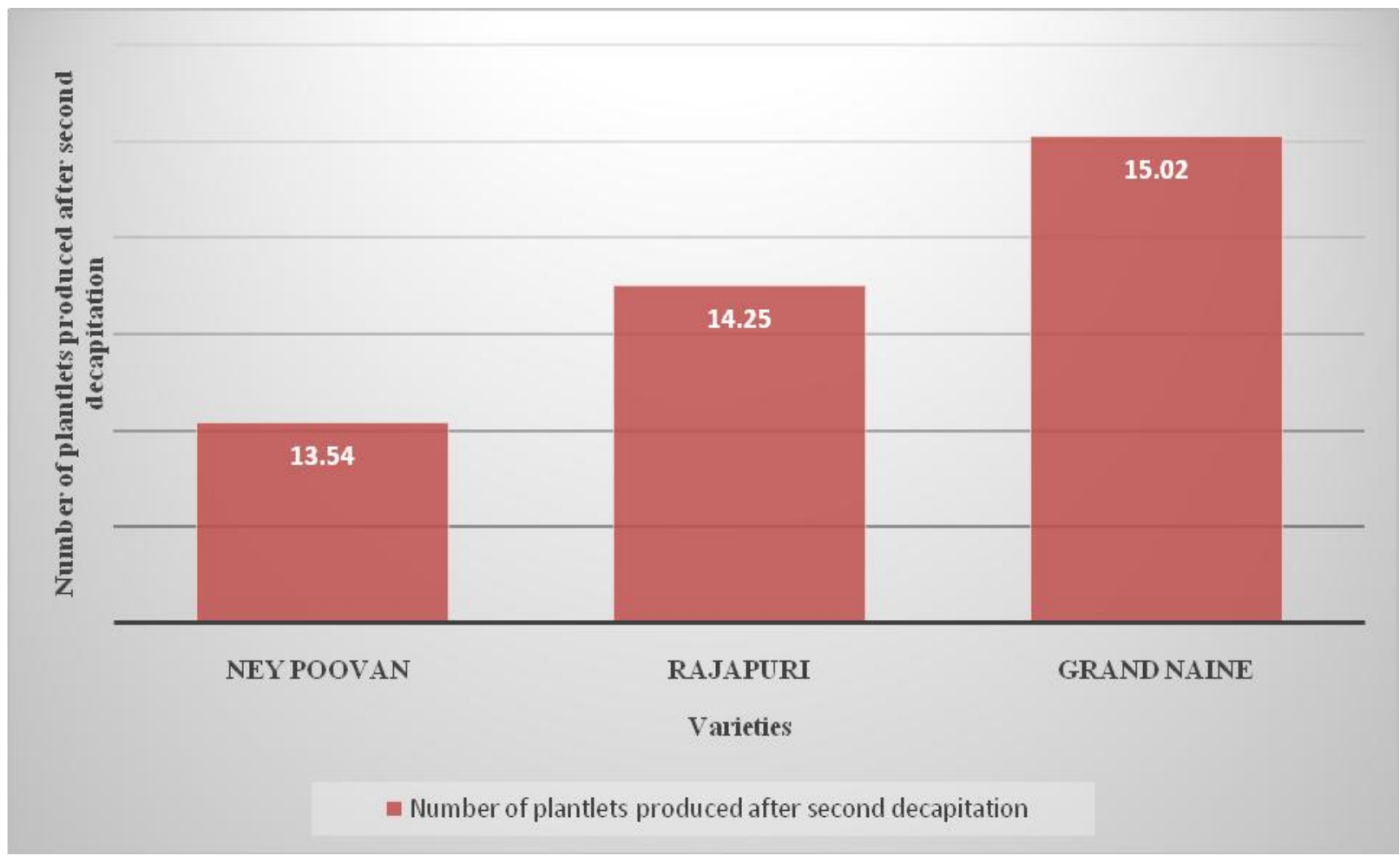


Fig.3 Varietal response to macro-propagation on total number of plantlets produced per corm

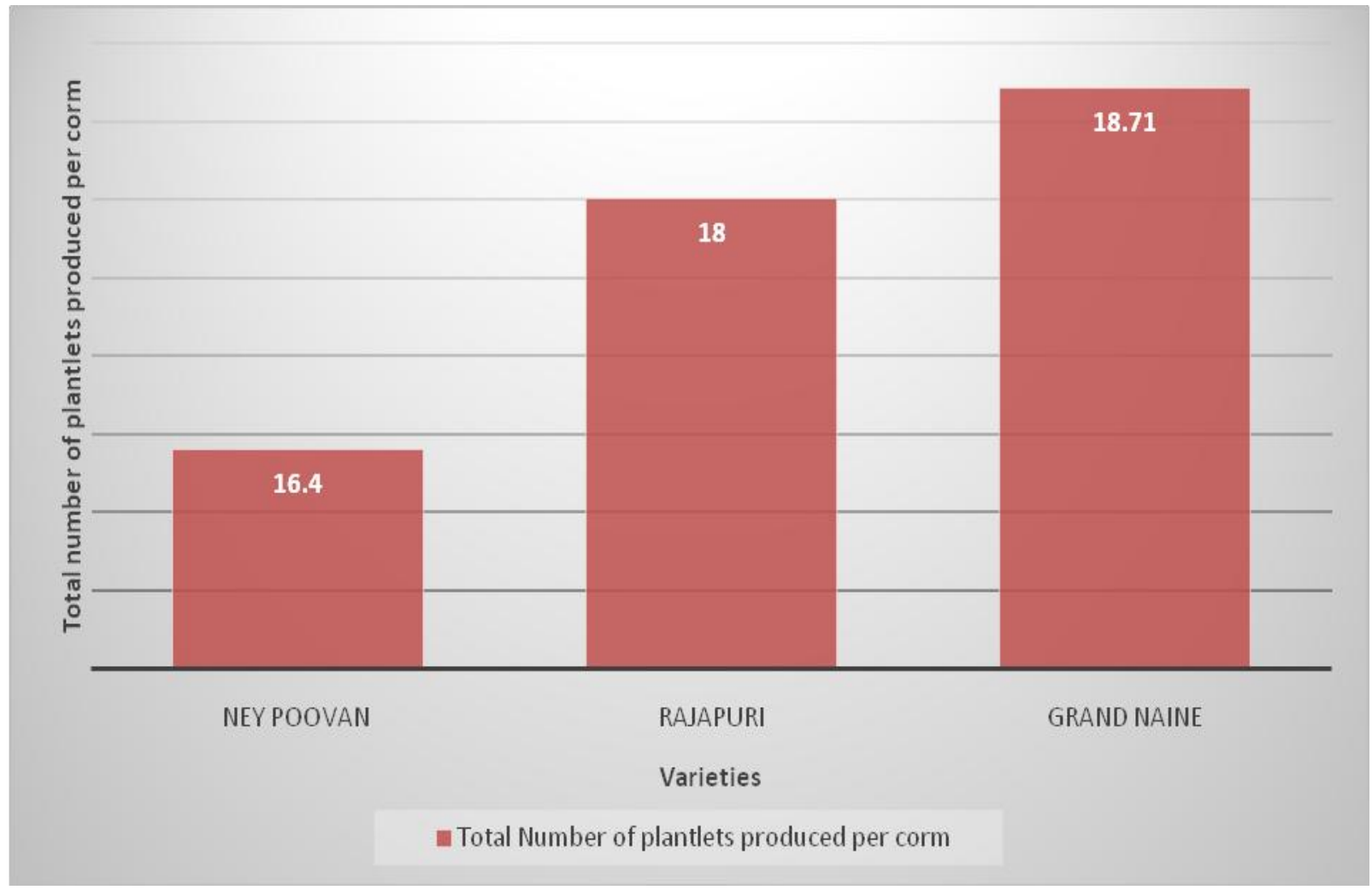

Table.1 Varietal response for early plantlet regeneration through macro-propagation of banana

\begin{tabular}{|l|c|c|}
\hline \multicolumn{1}{|c|}{ Varieties } & $\begin{array}{c}\text { Number of days taken for } \\
\text { first bud emergence }\end{array}$ & $\begin{array}{c}\text { Number of days for second } \\
\text { decapitation }\end{array}$ \\
\hline Ney Poovan & 30.80 & 61.42 \\
\hline Rajapuri & 43.71 & 70.20 \\
\hline Grand Naine & 34.71 & 72.25 \\
\hline S.Em \pm & $\mathbf{1 . 5 0}$ & $\mathbf{3 . 5 1}$ \\
\hline CD at 5\% & $\mathbf{4 . 4 7}$ & $\mathbf{1 0 . 4 3}$ \\
\hline
\end{tabular}

Table.2 Varietal response for plantlet regeneration in macro-propagation of banana

\begin{tabular}{|l|c|c|c|}
\hline \multicolumn{1}{|c|}{ Varieties } & $\begin{array}{c}\text { Number of primary } \\
\text { buds per corm }\end{array}$ & $\begin{array}{c}\text { Number of plantlets } \\
\text { produced after second } \\
\text { decapitation }\end{array}$ & $\begin{array}{c}\text { Total Number of } \\
\text { plantlets produced } \\
\text { per corm }\end{array}$ \\
\hline Ney Poovan & 2.74 & 13.54 & 16.40 \\
\hline Rajapuri & 3.68 & 14.25 & 18.00 \\
\hline Grand Naine & 3.74 & 15.02 & 18.71 \\
\hline S.Em \pm & $\mathbf{0 . 2 9}$ & $\mathbf{0 . 8 6}$ & $\mathbf{0 . 9 0}$ \\
\hline CD at 5\% & $\mathbf{0 . 8 7}$ & $\mathbf{N S}$ & NS \\
\hline
\end{tabular}


Table.3 Varietal response for root parameters in macro-propagation of banana

\begin{tabular}{|l|c|c|c|c|}
\hline \multicolumn{1}{|c|}{ Varieties } & $\begin{array}{c}\text { Number of } \\
\text { primary roots }\end{array}$ & $\begin{array}{c}\text { Length of longest } \\
\text { root }(\mathbf{c m})\end{array}$ & $\begin{array}{c}\text { Root fresh } \\
\text { weight }(\mathbf{g})\end{array}$ & Root dry weight (g) \\
\hline Ney Poovan & 17.31 & 66.68 & 10.54 & 3.19 \\
\hline Rajapuri & 7.80 & 32.28 & 7.00 & 2.89 \\
\hline Grand Naine & 6.48 & 35.62 & 6.08 & 2.76 \\
\hline S.Em \pm & $\mathbf{1 . 9 3}$ & $\mathbf{6 . 7 8}$ & $\mathbf{1 . 9 7}$ & $\mathbf{0 . 1 8}$ \\
\hline CD at 5\% & $\mathbf{5 . 7 4}$ & $\mathbf{2 0 . 1 5}$ & NS & NS \\
\hline
\end{tabular}

Table.4 Varietal response for shoot parameters in macro-propagation of banana

\begin{tabular}{|l|c|c|c|}
\hline \multicolumn{1}{|c|}{ Varieties } & Stem girth $(\mathbf{m m})$ & Shoot fresh wt. $(\mathbf{g})$ & Shoot dry wt. $(\mathbf{g})$ \\
\hline Ney Poovan & 27.33 & 58.40 & 4.28 \\
\hline Rajapuri & 29.66 & 81.90 & 5.83 \\
\hline Grand Naine & 26.10 & 69.57 & 5.82 \\
\hline S.Em \pm & $\mathbf{1 . 5 3}$ & $\mathbf{4 . 0 2}$ & $\mathbf{0 . 1 2}$ \\
\hline CD at 5\% & NS & $\mathbf{1 1 . 9 6}$ & $\mathbf{0 . 3 6}$ \\
\hline
\end{tabular}

Table.5 Calculation of cost economics for macro-propagation with varietal response in banana

\begin{tabular}{|c|c|c|c|c|c|}
\hline Treatments & No. of plantlets per treatment & Gross return & Total cost & Net return & B:C ratio \\
\hline $\mathrm{T}_{1}$ & 560 & 4480 & 1429.75 & 3050.25 & 2.13 \\
\hline $\mathrm{T}_{2}$ & 630 & 5040 & 1429.75 & 3610.25 & 2.52 \\
\hline $\mathrm{T}_{3}$ & 665 & 5320 & 1429.75 & 3891.25 & 2.72 \\
\hline
\end{tabular}

Table.6 Cost economics

\begin{tabular}{|c|l|c|}
\hline Sl. No. & \multicolumn{1}{|c|}{ Particulars } & Unit rate \\
\hline 1. & Sucker (per) & $5.00 \square$ \\
\hline 2. & Polybag $(42 \times 40 \mathrm{~cm})($ per) & $6.00 \square$ \\
\hline 3. & Sawdust & $2.50 \square / \mathrm{Kg}$ \\
\hline 4. & Cocopeat & $6.00 \square / \mathrm{Kg}$ \\
\hline 5. & Vermicompost & $3.50 \square / \mathrm{Kg}$ \\
\hline 6. & Farm Yard Mannure (FYM) & $2.00 \square / \mathrm{Kg}$ \\
\hline 7. & Pressmud & $1.00 \square / \mathrm{Kg}$ \\
\hline 8. & Trichodermaviridae & $170 \square / \mathrm{Kg}$ \\
\hline 9. & Vesicular ArbascularMycorrhizae (VAM) & $60 \square / \mathrm{Kg}$ \\
\hline 10. & Benzyl Amino Purine (BAP) & $189 \square / \mathrm{g}$ \\
\hline 11. & Thiadiazuron (TDZ) & $29,202 \square / \mathrm{g}$ \\
\hline 12. & Labour & $4200 \square$ \\
\hline 13. & Plant protection chemicals & $86 \square$ \\
\hline 14. & Per Plantlet cost & $8 \square$ \\
\hline
\end{tabular}




\section{Length of longest root $(\mathrm{cm})$}

Ney Poovan recorded significantly the longest length of root $(66.68 \mathrm{~cm})$ where as other two genotypes (Grand Naine-35.62 cm and Rajapuri- $32.28 \mathrm{~cm}$ ) recorded non-significant result for length of longest root (Table 3 and Plate 2).

Variety Ney Poovan showed significant difference compared to other varieties in case of length of longest root. Whereas, other two varieties such as Grand Naine and Rajapuri were on par with each other. (Anonymous, 2012).

These results indicated that Ney Poovan produced healthy plantlet with longer roots that will be helpful for better establishment of plant. Longer roots absorb water and nutrients from deeper layers.

\section{Root fresh weight (g)}

Root fresh weight for all genotypes showed non-significant results (Table 3). However maximum root fresh weight $(10.54 \mathrm{~g})$ was noticed in cv. Ney Poovan followed by Rajapuri $(7.00 \mathrm{~g})$ and the minimum in cv. Grand Naine $(6.08 \mathrm{~g})$.

Parameter root fresh weight did not shown significant difference among any of the treatments; however Ney Poovan produced more fresh weight of root followed by Rajapuri. Whereas, Grand Naine produced less root fresh weight. This may be due to varietal difference and difference in genome.

\section{Root dry weight (g)}

Root dry weight for all genotypes showed nonsignificant results (Table 3). However maximum root dry weight $(3.19 \mathrm{~g})$ was noticed in cv. Ney Poovan followed by Rajapuri (2.89 g) and the minimum in cv. Grand Naine (2.76 g). Parameter root dry weight did not showed significant difference among any of the treatments; however Ney Poovan produced more root fresh weight followed by Rajapuri. Whereas, Grand Naine produced less fresh weight of root. This may be due to varietal difference (genome).

\section{Stem girth (mm)}

Stem girth for all genotypes showed nonsignificant results. However maximum stem girth $(29.66 \mathrm{~mm})$ is noticed in Rajapuri followed by Nay Poovan $(27.33 \mathrm{~mm})$ and the lowest $(26.10 \mathrm{~mm})$ was observed in Grand Naine (Table 4).

Parameter stem girth did not showed significant difference among any of the treatments, however Rajapuri produced plantlets with thicker stem followed by Grand Naine (Anonymous, 2012). Whereas, Ney Poovan produced plantlets with thin stem. This may be due to varietal difference due to difference in genome.

\section{Shoot fresh weight (g)}

Cultivar Rajapuri recorded significantly the highest shoot fresh weight $(81.90 \mathrm{~g})$ whereas, other two genotypes (Graind Naine-69.57 g and Ney Poovan-58.40 g) recorded non-significant results for shoot fresh weight (Table 4).

Variety Rajapuri showed significant difference for the parameter fresh weight of shoot compared to other two varieties. Ney Poovan and Grand Naine were on par with each other. These results indicated that Rajapuri produced higher vegetation compared to other two varieties. This is due to varietal adaptability towards absorption of nutrients and having more vegetative part and hence higher shoot fresh weight.

\section{Shoot dry weight (g)}

Cultivar Rajapuri recorded significantly the highest shoot dry weight (5.83 g), which is on par with Grand Naine (5.82 g). However the genotype Ney Poovan recorded the less shoot dry weight with non-significant results $(4.28 \mathrm{~g})$ 
(Table 4). Significantly maximum shoot dry weight was produced by Rajapuri followed by Grand Naine. Since Rajapuri had higher shoot fresh weight consequently it produced higher shoot dry weight. This suggested that Rajapuri is a good nutrient absorber along with water. It may be one varietal character.

\section{Cost economics}

Among the three cultivars $\mathrm{T}_{3^{-}}$Grand Naine recorded maximum net return and $\mathrm{B}$ : $\mathrm{C}$ ratio respectively ( $\square 3891.25$ and 2.72) followed by $\mathrm{T}_{2}$ - Rajapuri ( $\square 3610.25$ and 2.52) while lowest net return and $\mathrm{B}$ : $\mathrm{C}$ ratio was recorded in $\mathrm{T}_{1^{-}}$ Ney Poovan ( $\square 3050.25$ and 2.13 respectively) (Tables 5 and 6). Among three cultivars used Grand Naine $\left(\mathrm{T}_{3}\right)$ recorded higher net return and $\mathrm{B}$ : $\mathrm{C}$ ratio, it was due to maximum plantlet production which is a varietal trait. Lower net return and $\mathrm{B}$ : $\mathrm{C}$ ratio was recorded in cultivar Ney Poovan $\left(T_{1}\right)$, it was due to lower plantlet production.

From the experiment it was found that cv. Ney Poovan given best results for number of primary roots, length of longest root, number of days taken for first bud emergence and number of days for second decapitation. Cultivar Rajapuri given best results for shoot fresh weight, shoot dry weight and number of primary bud per corm. Cultivar Grand Naine, performed well for shoot dry weight, number of primary buds per corm, number of days taken for first bud emergence. Hence it is found that, to get maximum number of plantlets all are suitable for macro-propagation however, when the quality parameters are considered Grand Naine found to be better through macropropagation.

\section{References}

Adane, G., 2015, Effects of different concentrations of BAP (6-Benzyl Amino Purine) and NAA (Naphthalene Acetic Acid) on banana (Musa spp.) cv. Giant Cavendish shoot proliferation. Int. J. Plant Res. 1(2): 36-43.

Ahmed, S., Sharma, A., Bhushan, B., Wali, V.K., Bakshi, P. and Singh A. K., 2014, Studies on hardening and acclimatization of micro propagated plantlets of banana cv. Grand Naine. The Bioscan, 9(3): 965967.

Anonymous, 2012, Macropropagation techniques in banana. In. Proceedings of group discussion of scientists of AICRP on fruits, work shop held at Y. S. R. Hortil. Univ.

Baiyeri, K. P., and Aba, S. C., 2005, Response of Musa species to macro-propagation. I: Genetic and initiation media effects on number, quality and survival of plantlets at pre nursery and early nursery stages. African. J. Biotechnol. 4(3): 223-228.

Faturoti, B., Tenkauno, A., Lemchi, J. and Nnaji, N., 2002, Rapid multiplication of plantain and banana. Macropropagtiontechniques. A pictorial guide. IITA Ibadan, Naigeria: 12.

Kashyap, B., and Dhiman, S. R., 2011, Effect of media on hardening of in-vitro multiplied plantlets of gloxinia and saintpaulia under low cost polytunnels. Int. J. Farm Sci.1 (2): 63-67.

Panse, V. G., and Sukhatme, P. V., 1967, Statistical methods for agricultural workers, Indian Council of Agricultural Research, New Delhi.: 152-161.

Swennen, R., 1990, Plantain cultivation under West African conditions: A reference manual. Int. Inst. Agic. Ibadan, Nigeria: 24.

Tenzens du Moncel, H., 1985, Le bananier plantain. Maisonneuve and Lasore, Paris: 143.

\section{How to cite this article:}

Pujar, D.U., A. M.Shirol, U. U.Pujar, S.S. Hiremath and Choudhury, P.R. 2017. Varietal Response on Plantlet Regeneration through Macro-Propagation in Banana (Musa spp. L.). Int.J.Curr.Microbiol.App.Sci. 6(9): 206-215. doi: https://doi.org/10.20546/ijcmas.2017.609.028 